\title{
Therapeutic adherence in outpatients with heart failure registered with a community pharmacy
}

\author{
Rosario Megret Despaigne*, Carlos Manuel Dutok Sánchez, Alam Sarfraz
}

Department of Pharmacy, Faculty of Natural Sciences, University of Oriente, Santiago de Cuba, Cuba

\begin{abstract}
A transverse descriptive study was carried out, according to the classification of therapeutic compliance, to evaluate adherence in 250 patients with a diagnosis of Heart Failure, registered with the health department of the municipality of Santiago de Cuba in 2009. The sample characterization was studied, with an assessment of adherence level and possible associated factors for sex, age and toxic habits. As an instrument for the work, data extraction was scheduled and the interview was carried out at patients' homes; the results were expressed in percentage and level of influence for associated factors. This was determined using the chi-square test. In the investigated population, adherence was greater for females, for age group 67-82 years, and toxic habits were found to have prevalence. Prevailing pharmacoterapies were digoxin, chlortalidone, captopril and isosorbide dinitrate, and a high level of adherence was found, both for the pharmacological and non-pharmacological treatments, in the studied sample. A good level of therapeutic adherence was found for $63.6 \%$ of the patients, regular level of adherence was found for $32 \%$ and only $4.4 \%$ or patients presented with poor adherence. Influencing factors were: knowledge of the treatment, number of medications, frequency of administration, and satisfaction with the service of pharmaceutical care.
\end{abstract}

Uniterms: Treatment adherence. Heart failure/pharmacological treatment. Community pharmacy.

Realizou-se estudo descritivo transversal, de acordo com a classificação de adesão à terapêutica, para avaliar a adesão em 250 pacientes com diagnóstico de disfunção cardíaca, registrada no departamento de saúde do município de Santiago de Cuba, em 2009. A caracterização da amostra foi estudada, com a avaliação do nível de adesão e possíveis fatores associado a sexo, idade e hábitos tóxicos. Como instrumento para o trabalho, esquematizou-se aa extração de dados e realizou-se a entrevista nas moradias dos pacientes. Os resultados foram expressos em porcentagem e em nível de influência dos fatores associados, determinados por meio do teste do Q quadrado. Na população sob investigação, a adesão foi maior para as mulheres da faixa etária de 67 a 82 anos, e os hábitos tóxicos foram prevalentes. Na amostra em estudo, as farmacoterapias predominantes foram digoxina, clortalidona, captopril e dinitrato de isossorbida e se observou alto nível de adesão tanto para os tratamentos farmacológicos quanto para os não-farmacológicos. Observou-se alto nível de adesão para $63,6 \%$ dos pacientes, nível regular para $32 \% 3$ somente $4,4 \%$ dos pacientes apresentaram baixa adesão. Os fatores que influenciaram foram conhecimento a respeito do tratamento, número de medicamentos, frequência de administração e satisfação com o serviço de atenção farmacêutica.

Unitermos: Adesão terapêutica. Insuficiência cardíaca/tratamento farmacológico. Farmácia comunitária.

\section{INTRODUCTION}

Worldwide, cardiovascular diseases are among the leading causes of death. In 2010, cases of death all

\footnotetext{
*Correspondence: R. M. Despaigne. Pharmacy Department, Natural Sciences Faculty, Universidad de Oriente. Patrício Lumumba Avenue, CP 90500, Santiago de Cuba, Cuba. E-mail: megretr@ent.uo.edu.cu
}

over the world increased by $36 \%$, against $31 \%$ in 1999 . Heart failure is a major and growing health problem, these days. The increase in heart failure incidence and prevalence, high morbidity and mortality, and the use of expensive resources constitute relevant challenges for modern day medicine. This is a chronic and progressive clinical syndrome. Incidences are increasing especially in industrialized countries, with extraordinary severity and 
grim prognosis. In Cuba, it was the leading cause of death in patients over 60 years in 2005, with 16,248 patients suffering from cardiovascular diseases in our province jurisdiction (Orduñez et al., 2005).

Heart failure is also referred to as congestive heart failure. This is a disorder in which the heart loses its ability to efficiently pump blood, causing insufficient supply of oxygen and nutrients to the body, which leads to fatigue and shortness of breath (Tamargo, Delpón, 2001).

Pharmacological treatment and changes in lifestyle should be prescribed to patients with heart failure. Lack of adherence is the main factor in destabilization and hospitalization. Adherence is defined as the appropriate behavior for individuals who, ultimately and effectively validate the prescription by a health professional (Lora, 2005).

Given that, our clinical services have conducted a study on prescribing and adherence for patients with heart failure. We were interested in investigating a larger number of patients and examining the factors that can influence adherence, a problem that results in the largest percentage of patients hospitalized for acute forms of this disease. Therefore, this study sets out to assess adherence in outpatients with congestive heart failure in the health system.

\section{METHOD}

A descriptive study of drug use was conducted for adherence classification, according with Díaz, et at. (2004), so as to evaluate adherence of patients with heart failure in the health care system.

\section{Sample characterization}

A total of 250 patients were randomly selected for the sample, from a universe of 504 patients categorized in 2009 at the "Armando Garcia" health department (Santiago of Cuba). The sample was characterized according to social variables such as age, sex, and toxic habits relating to the pathology under study.

\section{Level of adherence}

All patients underwent an interview at their home (Annex I) which collected data on the variables and others aspects, as follows.

\section{Drug treatment}

This item specified compliance with the use of prescription medications for heart failure, including dose and frequency interval for each drug, as described in the medical certificate.

\section{Non-drug treatment}

This item specified whether the patient met the dietary measures in terms of cutting down on salt and saturated fats, practicing physical activity according to their illness and limitating toxic habits (coffee, snuff and alcohol).

To determine the percentage of compliance for each patient, the following equation was used, at the discretion of researchers:

$\%$ Compliance $=\frac{(\text { number of variables met } \times 100)}{\text { total variables }}$

where total variables $=6$ (prescription medications, dose, interval, dietary measures, physical activity according to illness, and limitation of toxic habits)

Later, the following categories were established to define the level of adherence, according to the authors' criteria:

Good adherence: For patients who achieved more than $80 \%$ compliance.

Regular adherence: For patients who achieved 50-80\% compliance.

Bad adherence: For patients who achieved less than $50 \%$ compliance.

\section{Factors associated with adherence}

The possible factors associated with patient compliance were analysed, with the aim of establishing the existence of an association between level of compliance and the possible factors, as follows:

A. Patient-dependent factors: sex, age, knowledge about the disease and treatment.

B. Treatment-dependent factors: amount of medication and frequency of intake.

C. Health care-dependent factors: access to the Pharmaceutical Service, satisfaction with the care provided by the Pharmacy Services, and frequency of medical appointments.

\section{Processing of results}

Absolute frequencies and percentages were used as a measure of summary for the qualitative variables. The statistical significance for dependency of the different factors was calculated using the test itself, and a parametric Chi-squared test (x2), in which adherence was the main 
variable, and patient-dependent factors, treatment and pharmaceutical care were the independent variables.

\section{RESULTS AND DISCUSSION}

\section{Sample characterization}

The study included 250 patients with heart failure, of which $65.6 \%$ were women and $34.4 \%$ were men, as shown in Table I. The selected sample shows prevalence of women suffering from the disease. This result is in line with previous studies, but there are no reports that sex is a predisposing factor to the onset of heart failure (Roca, 2002), so the result may be caused by the random selection of the sample, which included more women than men.

In terms of age group, the sample shows an increased incidence of patients aged between 67-82 years, with $46.4 \%$ (Table I). This result can be attributed to the fact that, as age advances, there is a noticeable decrease in the stimulation of receptor $\beta$ - adrenergic, manifested by decrease in the inotropic, vasodilator and chronotropic response. Moreover, it has been reported that senescence causes a decline in cardiovascular function and that the severity of heart disease increases with age (Farreras, 2000).

\section{Level of therapeutic adherence}

In terms of the level of adherence, Figure 1 shows that $63.6 \%$ of patients under study conformed well to the treatment. These results are consistent with the literature, in which compliance rates indicate that $40-60 \%$ of patients generally accept drug therapy. Regarding the drug treatment, it was observed that all patients met the prescribed doses of medications used for heart failure, although some did not meet the specified intervals. This result can be attributed to the fact that, in this disease, multiple medications are tipically prescribed, and the frequency of administration is very high, so that patients are likely to stop their normal duties to take a dose, which could lead to neglect or refusal by patients.

When evaluating non-pharmacological treatment, we found that $97 \%$ of the sample adhered to the prescribed plan of diet and physical activity. That was not the case, however, for the limitations of toxic habits, chiefly coffee intake. Although patients had acceptable knowledge about these restrictions, they failed to adhere to the prescribed indications. Given that coffee intake is not totally contraindicated in heart failure, we believe that the patients interviewed had made adjustments for major lifestyle changes that this disease requires (A1fonso, 2004).

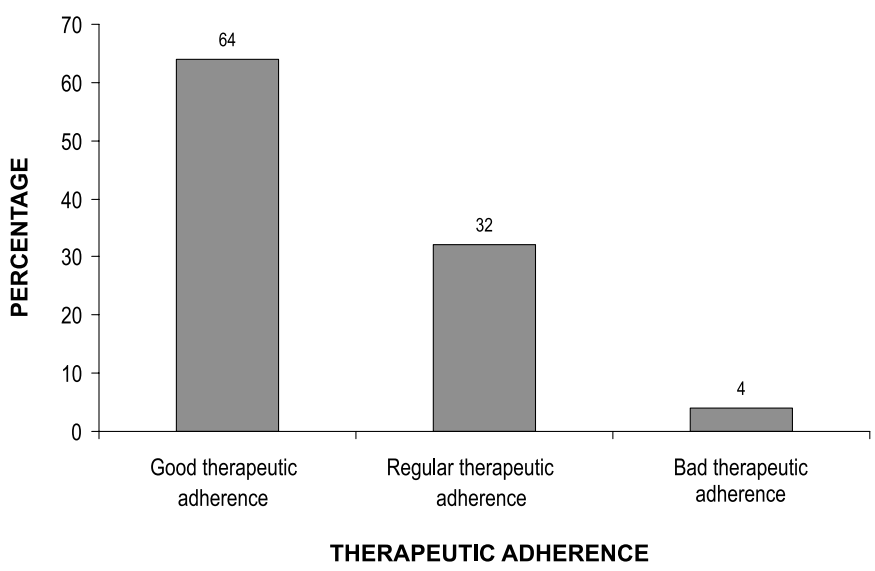

FIGURE 1 - Level of therapeutic adherence of the patients with a diagnosis of heart failure.

\section{Factors associated with therapeutic adherence}

Table II shows the association of patient-dependent factors with the level of adherence. In terms of gender, there is a predominance of good adhesion in women, with $42 \%$. This finding is consistent with that reported in other studies, which have found criteria suggesting that women comply more with the treatment than men (Lifshitz, 2007), because they are more concerned about maintaining their

TABLE I - Distribution of patients with cardiovascular disease, by age and sex

\begin{tabular}{lcccccc}
\hline \multirow{2}{*}{$\begin{array}{l}\text { Age group } \\
\text { (years) }\end{array}$} & \multicolumn{2}{c}{ Female } & \multicolumn{2}{c}{ Male } & \multicolumn{2}{c}{ Total } \\
\cline { 2 - 7 } & Number* & $\%$ & Number & $\%$ & Number & $\%$ \\
\hline $31-50$ & 5 & 2 & 4 & 1.6 & 9 & 3.6 \\
$51-66$ & 30 & 12 & 20 & 8 & 50 & 20 \\
$67-82$ & 71 & 28.4 & 45 & 18 & 116 & 46.4 \\
$\geq 83$ & 58 & 23.2 & 17 & 6.8 & 75 & 30 \\
\hline total & 164 & 65.6 & 86 & 34.4 & 250 & 100 \\
\hline
\end{tabular}

* Number of the patients $=250$ 
TABLE II - Sex associated with therapeutic adherence

\begin{tabular}{lcccccccc}
\hline \multirow{2}{*}{ Sex } & \multicolumn{2}{c}{$\begin{array}{c}\text { Good therapeutic } \\
\text { adherence }\end{array}$} & \multicolumn{2}{c}{$\begin{array}{c}\text { Regular therapeutic } \\
\text { adherence }\end{array}$} & \multicolumn{2}{c}{$\begin{array}{c}\text { Bad therapeutic } \\
\text { adherence }\end{array}$} & \multicolumn{2}{c}{ Total } \\
\cline { 2 - 10 } & Number & $\%$ & Number & $\%$ & Number & $\%$ & Number & $\%$ \\
\hline Male & 54 & 21.6 & 28 & 11.2 & 4 & 1.6 & 86 & 34.4 \\
Female & 105 & 42 & 52 & 20.8 & 7 & 2.8 & 91 & 36.4 \\
\hline Total & 159 & 63.6 & 80 & 32 & 11 & 4.4 & 250 & 100 \\
\hline
\end{tabular}

$\mathrm{x} 2=0.05 \quad \mathrm{~g} .1=2 \quad \mathrm{p}>0.05$

health. However, the characteristics of the sample may be influencing the results, as the statistical analysis $(p>0.05)$ did not reflect the level of adherence depending on this factor.

In analyzing the impact of age groups (Table III), there was no significant dependency $(p>0.05)$ with the level of adherence. We must bear in mind that, at any age, patients with chronic diseases should be given their medication and follow appropriate changes in lifestyle, which will maintain the disease stable.

Significant influence $(p>0.05)$ was not found from the knowledge of the disease (Table IV). However, it was observed that $78.8 \%$ of the patients have acceptable knowledge about their disease. This result is in line with other studies, which establishes the importance of each patient knowing the broader aspects of their pathology, which should prompt them to adopt positive behavior in terms of their medication and lifestyle.

In terms of the factor knowledge about the treatment (Table V), a statistically significant dependency $(\mathrm{p}<0.05)$ was observed, with $85 \%$ of patients having achieved acceptable knowledge about their treatment dose and interval. This result coincides with other reports, which have shown that a better understanding of the disease and treatment brings better adherence. (Noda, et al., 2008; Alfonso, 2006).

Treatment-dependent factors are presented in Tables VI and VII, and it was observed that the number of medications and frequency of administration significantly influenced $(p<0.05)$ the level of adherence. We found that most patients who achieved a good level of adherence consumed up to 3 drugs, up to 3 times a day. This result could be due to the fact that, even with multiple medications, patients must

TABLE III - Age associated with therapeutic adherence

\begin{tabular}{lcccccccc}
\hline $\begin{array}{l}\text { Age } \\
\text { (years) }\end{array}$ & \multicolumn{2}{c}{$\begin{array}{c}\text { Good therapeutic } \\
\text { adherence }\end{array}$} & \multicolumn{2}{c}{$\begin{array}{c}\text { Regular therapeutic } \\
\text { adherence }\end{array}$} & \multicolumn{2}{c}{$\begin{array}{c}\text { Bad therapeutic } \\
\text { adherence }\end{array}$} & \multicolumn{2}{c}{ Total } \\
\cline { 2 - 10 } & Number & $\%$ & Number & $\%$ & Number & $\%$ & Number & $\%$ \\
\hline $31-50$ & 3 & 1.2 & 5 & 2 & 1 & 0.4 & 9 & 3.6 \\
$51-66$ & 28 & 11.2 & 20 & 8 & 2 & 0.8 & 50 & 20 \\
$67-82$ & 78 & 31.2 & 32 & 12.8 & 6 & 2.4 & 116 & 46.4 \\
$\geq 83$ & 50 & 20 & 23 & 9.2 & 2 & 0.8 & 75 & 30 \\
\hline Total & 159 & 63.6 & 80 & 32 & 11 & 4.4 & 250 & 100 \\
\hline
\end{tabular}

$\mathrm{x} 2=7.02 \quad$ g. $1=6 \quad \mathrm{p}>0.05$

TABLE IV - Knowledge about the disease associated with therapeutic adherence

\begin{tabular}{lcccccccc}
\hline $\begin{array}{l}\text { Knowledge } \\
\text { about the } \\
\text { disease }\end{array}$ & \multicolumn{2}{c}{$\begin{array}{c}\text { Good therapeutic } \\
\text { adherence }\end{array}$} & \multicolumn{2}{c}{$\begin{array}{c}\text { Regular therapeutic } \\
\text { adherence }\end{array}$} & \multicolumn{2}{c}{$\begin{array}{c}\text { Bad therapeutic } \\
\text { adherence }\end{array}$} & \multicolumn{2}{c}{ Total } \\
\cline { 2 - 9 } & Number & $\%$ & Number & $\%$ & Number & $\%$ & Number & $\%$ \\
\hline Acceptable & 127 & 50.8 & 63 & 25.2 & 7 & 2.8 & 197 & 78.8 \\
Unacceptable & 32 & 12.8 & 17 & 6.4 & 4 & 1.6 & 53 & 21.2 \\
\hline Total & 159 & 63.6 & 80 & 32 & 11 & 4.4 & 250 & 100 \\
\hline
\end{tabular}

$\mathrm{x} 2=1.62 \quad$ g.l $=2 \quad \mathrm{p}>0.05$ 
TABLE V - Knowledge about the treatment associated with therapeutic adherence

\begin{tabular}{|c|c|c|c|c|c|c|c|c|}
\hline \multirow{2}{*}{$\begin{array}{l}\text { Knowledge } \\
\text { about the } \\
\text { treatment }\end{array}$} & \multicolumn{2}{|c|}{$\begin{array}{c}\text { Good therapeutic } \\
\text { adherence }\end{array}$} & \multicolumn{2}{|c|}{$\begin{array}{c}\text { Regular therapeutic } \\
\text { adherence }\end{array}$} & \multicolumn{2}{|c|}{$\begin{array}{c}\text { Bad therapeutic } \\
\text { adherence }\end{array}$} & \multicolumn{2}{|c|}{ Total } \\
\hline & Number & $\%$ & Number & $\%$ & Number & $\%$ & Number & $\%$ \\
\hline Unacceptable & 23 & 9.2 & 8 & 3.2 & 5 & 2 & 36 & 14.4 \\
\hline Total & 159 & 63.6 & 80 & 32 & 11 & 4.4 & 250 & 100 \\
\hline
\end{tabular}

$\mathrm{x} 2=9.86 \quad \mathrm{~g} .1=2 \quad \mathrm{p}<0.05$

TABLE VI - Amount of medication associated with therapeutic adherence

\begin{tabular}{lcccccccc}
\hline \multirow{2}{*}{$\begin{array}{l}\text { Amount of } \\
\text { Medication }\end{array}$} & \multicolumn{2}{c}{$\begin{array}{c}\text { Good therapeutic } \\
\text { adherence }\end{array}$} & \multicolumn{2}{c}{$\begin{array}{c}\text { Regular therapeutic } \\
\text { adherence }\end{array}$} & \multicolumn{2}{c}{$\begin{array}{c}\text { Bad therapeutic } \\
\text { adherence }\end{array}$} & Total \\
\cline { 2 - 8 } & Number & $\%$ & Number & $\%$ & Number & $\%$ & Number & $\%$ \\
\hline$\leq 3$ & 99 & 39.6 & 25 & 10 & 4 & 1.6 & 128 & 51.2 \\
$\geq 4$ & 60 & 24 & 55 & 22 & 7 & 2.8 & 122 & 48.8 \\
\hline Total & 159 & 63.6 & 80 & 32 & 11 & 4.4 & 250 \\
\hline
\end{tabular}

$\mathrm{x} 2=21.50 \quad$ g.l $=2 \quad \mathrm{p}<0.05$

TABLE VII - Frequency of administration associated with therapeutic adherence

\begin{tabular}{|c|c|c|c|c|c|c|c|c|}
\hline \multirow{2}{*}{$\begin{array}{l}\text { Frequency of } \\
\text { administration }\end{array}$} & \multicolumn{2}{|c|}{$\begin{array}{c}\text { Good therapeutic } \\
\text { adherence }\end{array}$} & \multicolumn{2}{|c|}{$\begin{array}{c}\text { Regular therapeutic } \\
\text { adherence }\end{array}$} & \multicolumn{2}{|c|}{$\begin{array}{c}\text { Bad therapeutic } \\
\text { adherence }\end{array}$} & \multicolumn{2}{|c|}{ Total } \\
\hline & Number & $\%$ & Number & $\%$ & Number & $\%$ & Number & $\%$ \\
\hline$\geq 4$ & 8 & 3.2 & 11 & 4.4 & 3 & 1.2 & 22 & 8.8 \\
\hline Total & 159 & 63.6 & 80 & 32 & 11 & 4.4 & 250 & 100 \\
\hline
\end{tabular}

$\mathrm{x} 2=9.93 \quad \mathrm{~g} .1=2 \quad \mathrm{p}<0.05$

comply with the treatment, once non-compliance can lead to recurrent decompensation, with subsequent hospitalizations. It is known that heart failure requires the use of several drugs. In our study, the most representative therapeutic regimen was the one that prescribed digoxin, chlorthalidone, isosorbide dinitrate, and captopril(14).

With respect to care-dependent factors (Table VIII), it was observed that access to the pharmaceutical service was not an influencing factor $(p>0.05)$ in adherence, because patients can fill their prescriptions at pharmacies near their home/community. Additionally, the patients who showed inadequate access can still obtain their drugs because, although they are unable to run errands themselves, they usually send a family member to get their medication.

TABLE VIII - Access to the Pharmaceutical Service associated with therapeutic adherence

\begin{tabular}{|c|c|c|c|c|c|c|c|c|}
\hline \multirow{2}{*}{$\begin{array}{l}\text { Access to the } \\
\text { pharmaceutical } \\
\text { service }\end{array}$} & \multicolumn{2}{|c|}{$\begin{array}{c}\text { Good therapeutic } \\
\text { adherence }\end{array}$} & \multicolumn{2}{|c|}{$\begin{array}{c}\text { Regular therapeutic } \\
\text { adherence }\end{array}$} & \multicolumn{2}{|c|}{$\begin{array}{c}\text { Bad therapeutic } \\
\text { adherence }\end{array}$} & \multicolumn{2}{|c|}{ Total } \\
\hline & Number & $\%$ & Number & $\%$ & Number & $\%$ & Number & $\%$ \\
\hline Unacceptable & 76 & 30.4 & 33 & 13.2 & 3 & 1.2 & 112 & 44.8 \\
\hline Total & 159 & 63.6 & 80 & 32 & 11 & 4.4 & 250 & 100 \\
\hline
\end{tabular}

$\mathrm{x} 2=2.35 \quad \mathrm{~g} .1=2 \quad \mathrm{p}>0.05$ 
TABLE IX - Satisfaction with care in the Pharmacy Services associated with therapeutic adherence

\begin{tabular}{lcccccccc}
\hline $\begin{array}{l}\text { Satisfaction } \\
\text { with care in } \\
\text { the pharmacy } \\
\text { services }\end{array}$ & $\begin{array}{c}\text { Good therapeutic } \\
\text { adherence }\end{array}$ & \multicolumn{2}{c}{$\begin{array}{c}\text { Regular therapeutic } \\
\text { adherence }\end{array}$} & \multicolumn{2}{c}{$\begin{array}{c}\text { Bad therapeutic } \\
\text { adherence }\end{array}$} & Total \\
\cline { 2 - 9 } & Number & $\%$ & Number & $\%$ & Number & $\%$ & Number & $\%$ \\
Low & 11 & 4.4 & 10 & 4 & 2 & 0.8 & 23 & 9.2 \\
Media & 70 & 28 & 18 & 7.2 & 3 & 1.2 & 91 & 36.4 \\
High & 78 & 31.2 & 52 & 20.8 & 6 & 2.4 & 136 & 54.4 \\
\hline Total & 159 & 63.6 & 80 & 32 & 11 & 4.4 & 250 & 100 \\
\hline
\end{tabular}

$\mathrm{x} 2=12.34 \quad$ g. $1=4 \quad \mathrm{p}<0.05$

TABLE X - Frequency of medical visits associated with therapeutic adherence

\begin{tabular}{lcccccccc}
\hline $\begin{array}{l}\text { Frequency of } \\
\text { medical visits }\end{array}$ & \multicolumn{2}{c}{$\begin{array}{c}\text { Good therapeutic } \\
\text { adherence }\end{array}$} & \multicolumn{2}{c}{$\begin{array}{c}\text { Regular therapeutic } \\
\text { adherence }\end{array}$} & \multicolumn{2}{c}{$\begin{array}{c}\text { Bad therapeutic } \\
\text { adherence }\end{array}$} & \multicolumn{2}{c}{ Total } \\
\cline { 2 - 11 } & Number & $\%$ & Number & $\%$ & Number & $\%$ & Number & $\%$ \\
\hline Acceptable & 32 & 12.8 & 15 & 6 & 5 & 2 & 52 & 20.8 \\
Unacceptable & 127 & 50.8 & 65 & 26 & 6 & 2.4 & 198 & 79.2 \\
\hline Total & 159 & 63.6 & 80 & 32 & 11 & 4.4 & 250 & 100 \\
\hline
\end{tabular}

$\mathrm{x} 2=4.31 \quad$ g.l $=2 \quad \mathrm{p}>0.05$

The assessment of patient satisfaction (Table XIX) showed significant dependency $(\mathrm{p}<0.05)$ with the level of adherence. It was observed that the largest number of patients with good adherence showed high satisfaction with the pharmacy services, which suggests that patient care regarding treatment, frequency intervals, clarifications, and doubts may affect proper enforcement.

The frequency of medical examination showed no significant dependency (Table $\mathrm{X}$ ) with regard to adherence to the treatment, and it was observed that $50.8 \%$ of patients with good adherence had an inadequate rate of appointments with a doctor. Patients only visit the doctor to obtain their drug prescriptions, in acute episodes or for other occasional causes. In this respect, some authors suggest that to increase adherence should be from the education and professional preparation of health to develop compelling communication, affective and effective, to simplify treatment regimens as well as schedule frequency of patient visits to allow for appropriate interaction between health care professionals and patient (Sedano,2009).

Of the factors analyzed, only one significantly influenced adherence, namely patient's knowledge about the treatment. Among patients, $85.6 \%$ achieved acceptable knowledge about their treatment, which coincides with other reports which have shown that a better understanding of the disease and treatment cause better adherence to the treatment.
Treatment-dependent: in terms of the number of medications and frequency of administration, it was found that most patients who achieved a good level of adherence consume up to 3 drugs, up to 3 times a day.

Care-dependent: in terms of patient satisfaction, it was observed that patients with good adherence expressed high satisfaction with the pharmacy service. It has been reported that patient satisfaction, from an emotional viewpoint on the relationship established with health professionals, has been associated with increased adherence (Heredia, Megret, 2005).

Despite the prevailing good adherence, we consider it necessary for health professionals to provide health education to patients with heart failure, especially the professional pharmacist, thus helping improve these patients' quality of life.

The biggest problem for adherence studies is that there no "gold standard" for fully measuring this pattern of behavior. The boundaries between good and poor adherence are not uniformly defined, and therefore any system that is used only in practice will provide a more or less accurate approximation of the real situation.

\section{CONCLUSIONS}

In the investigated population, there was prevalence of women, of the age group of 67-82 years and a greater 
incidence of coffee intake as a toxic habit. The prevailing pharmacoterapy was digoxin, chlortalidone, captopril and isosorbide dinitrate. A good level of therapeutic adherence was observed in the patients. This level of adherence was influenced by factors such as knowledge about the treatment, number of medications, frequency of administration, and satisfaction with the care in the pharmacy service. Most of the investigated patients adopted positive behaviors that allowed for good adherence to the treatment.

\section{REFERENCES}

ALFONSO, M. Acerca del concepto de adherencia terapéutica. Rev. Cub. Salud Pub., v.30, n.4, p.48-52, 2004.

ALFONSO, M. Repercusiones para la salud pública de la adherencia terapéutica deficiente. Rev. Cub. Salud Pub., v.32, n.3, p.11-15, 2006.

DIAZ, R.M.; MENDOZA, M.E.; BELMONT, J. Validación de un instrumento para evaluar la adherencia terapéutica en diabéticas durante el embarazo. Perinatol. Reprod. Hum., v.18, n.4, p. 217-224, 2004.

FARRERAS, R. Tratado de medicina interna. Madrid: Harcourt, S.A., 2000. p.112-123.

HEREDIA, Y.; MEGRET, R. Adhesión al tratamiento en pacientes diabéticos. Rev. Aten. Farm., v.7, n.6, p.438-445, 2005 .

LIFSHITZ, A. Importancia y complejidad de la adherencia terapéutica. Rev. Med. Inst. Mex. Seguro Soc., v.45, n.4, p.309-310, 2007.
LORA, E. Adherencia al tratamiento del asma en el paciente pediátrico y sus cuidadores. Rev. Prac. Aten. Prim., v.7, n.2, p.97-105,2005.

NODA, J.; PÉREZ, E.; MÁLAGA, G. Conocimientos sobre su enfermedad en pacientes con diabetes mellitus tipo 2 que acuden a hospitales generales. Rev. Med. Hered., v.19, n.2, p.68-72, 2008.

ORDUÑEZ, P.O.; COOPER, R.S.; ESPINOSA, B.; IRAOLA, M.; BERNAL, J.L.; LA ROSA, Y. Enfermedades cardiovasculares en Cuba. Rev. Cub. Salud Pub., v.3, n.4, p.44-50, 2005.

ROCA, G. Insuficiencia cardiaca. In: ROCA, G., (Ed.). Temas de medicina interna. Habana: Editorial Ciencias Médicas, 2002. Tomo I, cap.27, p.304-324.

SEDANO, E. Funciones del farmacéutico de Atención Primaria. Available at: <www.sefap.org/webs/funciones $>$. Accessed on: 12 jul. 2009.

TAMARGO, J.; DELPÓN, E. Farmacología de la insuficiencia cardiaca I. Glucósidos digitálicos y otros inotrópicos. In: FLORES, J., (Ed.). Farmacología humana. 3.ed. Madrid: Masson, SA, 2001. p.609-626.

Received for publication on $14^{\text {th }}$ March 2011 Accepted for publication on $13^{\text {th }}$ September 2011

\section{Annex I}

Patient interview

Patient:

You are participating in an investigation pertaining to the Pharmaceutical Service; your information will help improve services and patient education information provided by the pharmacy, which will ensure rational use of medication. Thank you for your cooperation.

Are you taking medications for heart failure in the amount (dose) prescribed by your doctor? Medication

Dosage

Did you manage to take medications for heart failure in the schedule (dosing interval)? Range

Drug 
What do you do when you forget to take any medication?

$\square$ I do not take it $\quad \square$ I take the double dose $\square$ I take it when I remember

Have you stopped taking their medication at some point?

$\square$ Yes $\quad \square$ No $\quad$ When Why?

What quantity of salt you add to your food? $\square$ Little $\quad \square$ Average $\quad \square$ A lot

Which type of fat you use? $\square$ Oil $\square$ Fats

Has your doctor forbidden any kind of physical exercise, due to your disease? Which?
$\square$ Walking
$\square$ Bicycling
$\square$ Climbing stairs $\square$ None

Do you drink coffee?
$\square$ No
$\square$ Yes
$1-2$ cups/day
3-4 cups/day
More

Do you drink alcohol? $\square$ Yes $\square$ No

Do you smoke? $\square$ Yes $\square$ No

Do you know about your disease? $\square$ Yes $\square$ No

Do you know why you are taking medication for your heart treatment?
$\square$ Yes
$\square$ No
A little

Do you get the medication from the pharmacy? $\square$ Yes $\square$ No

Are you satisfied with the care provided by the Pharmacy Department?
$\square$ Not much
$\square$ Average
$\square$ Completely satisfied

How often do you visit your family doctor? 